почти одинаковая величина. Равномьрное сдавливаніе мозжечка послужило, вю́роятно, причиной отсутствія вынужденныхъ движевій, направленныхъ преимущественно въ гакую-либо одну сторону, вакъ это наблюдается при одностороннихъ поражепораженіяхъ мозжечка.

\title{
Н. Донсковъ.
}

\section{Физіологическая химія.}

Д-рэ А. И. Ющенко. Вліяніе тиреоидина, спермина и адреналина, а также удаленія щитовидной зелезы и яичект на овислительные процессы, ядовитость мочи и дыхательный газо0бминъ у животныхъ. Русскій Врачъ. I908.

Изсльду процессы овисленія и яовитость мочи у душевно-больныхъ людей, обықновенно приходится огравичиваться выясненіемъ повышенія и пониженія шхъ, болье же глубокое изсль'дованіе этихь продессовт надь людьми пока представляется затруднительным. Для болье тлубоваго изучевія әтого дыла приходится пзучать его на жшвотныхь и затьмь переносить на людей. Авторь изсльдоваль искуственную таперсеврецію и асекрецію щитовидной железы, яичекь и надпочечных' железъ на животныхь и даеть сльдующіе результаты. Вводя жавотнымъ тиреовдинъ и адреналинъ, можно вызвать у нихь повыпеніе ядовитости мочи; если же явленія отравленія животнаго достигали сильной степени, то ядовитость мочи начинала падать; очевидно, организмь не могь уже справиться скядовигыми началами и животное погиорало. При удаленіи части щитовидной жельзы ядовигость мочи сильно увеличивалась, животное чувствовало себя удовлетворительно; при удалевіп всей жельзы, ядовитость мочи сначала повыпалась, а ватьм, подала оть нақопленія дда. Ть же явленія, въ̌роятно, получатся и при удаленіи надпочечнивовъ. Введеніе въ органвзь спермина и удалевіе мужскихь половыхъ жельвь тавже вліяло на ядовитость мочи, но измиенія ея далево не достигали той степени и опредъ́енности, кањъ при отравленіи адреналиномъ и особенно при тиреоддимы и тиреодектоміи. Повышеніе оқислительныхъ процессовъ наблюдалось у животныхъ при тиреодектоміи, при тяжелыхь явленіяхъ отравленія тиреоидиномъ, адреналиномъ и сперминомъ. 
Повышеніе окислительныхъ процессовъ найдено при отравленіи животных'ь тиреоидиномъ, адреналиномь, посль' удаленія

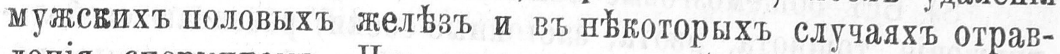
ленія спермивом'ь. Что касается газообмъна, то подъ вліяніемъ тиреоидина, поға ве наступали тяжелыя явленія отравленія, онъ повыпался, при чемъ главнымъ образомъ увеличввалось поглощеніе $\mathrm{O}_{2}$. Повыпался газообмћнъ и въ нищоторыхь случаяхъ отравлевія сперминомъ. Посль удаленія япчев газообмьнъ сначала даже повыпался, а затьмъ ньсколько повижался. Подъ вліяніекъ хроническаго отравленія небольшими пріемами адреналина выдыленіе $\mathrm{CO}_{2}$ повышалось, а поглощеніе $\mathrm{O}_{2}$ уменьшажось, или оставалось безь измьненій. Всь эти данныл им'ьють весьма важное значеніе и при встр'ьчьы съ различными аномаліями у душевно больныхъ людей. Это не первая уже экспериментальная работа автора, тынъ болье дълающая ему честь, что онъ стоить въ учебномъ отношеніи внб университетсқихъ кабинетовъ п лабораторій и производить эти пзсльовованія sua sponte.

\section{Проф. П. И. Ковалевскій}

\section{Невропатологія.}

B. М. Верзиловъ. Къ симтоматологіи киеть мозжечка, Журналь невропат. и псих. имени С. С. Корсакова. І908. жн. : -4 .

Авторъ описываеть собственныя наблюденія надъ 5 больными ст кистами мозжечка. На основаніи собственныхъ ваблюденій и обвора литературы по данному вопросу онъ приходить къ сльдующимъ вывидамт.

1) Квсты мозжечқа чаще всего наблюдаются въ возрасти между 20 и 30 г.

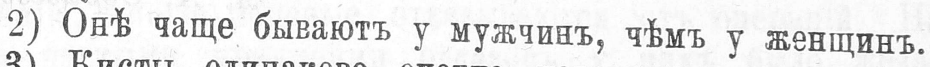

3) Кисты одинаћово охотно поражають кањь правое, такь и львое полупаріе мовжечка.

4) Травмы въ большинств'ы случаевъ не играють этіологичесвой роли въ пропсхожденіи висть мозжечка.

5) Начало бользнш большею частью внезапное.

6) Продолжительность больвзни въ большинствь́ случаевь незначительная; чаще всего ов" протекають меньще года. 